Богдан, Світлана. «Епістолярний ідіолект Лесі Українки в інтер'єрі родинної комунікації: уліта». Лінгвостилістичні студії, вип. 13, 2020, с. 16-34.

Bohdan, Svitlana. "Lesia Ukrainka's Epistolary Idiolect in the Interior of Family Communication: Ulita". Linguostylistic Studies, iss. 13, 2020, pp. 16-34.

Удк 821.161.2-6 Українка

https://doi.org/10.29038/2413-0923-2020-13-16-34

\title{
ЕПІСТОЛЯРНИЙ ІДІОЛЕКТ ЛЕСІ УКРАЇНКИ В ІНТЕР'ЄРІ РОДИННОЇ КОМУНІКАЦЇ̈: УЛІТА
}

\author{
Світлана Богдан \\ Волинський національний університет імені Лесі Українки, \\ Луцьк, Україна
}

\begin{abstract}
У статті на матеріалі епістолярних текстів розглянуто домінувальні розрізнювальні ознаки родинної комунікації Косачів; проаналізовано особливу стильову тональність їхнього листування, яка актуалізована насамперед у використанні своєрідної метамови, зокрема, лексичних одиниць, що мають статус регулятивності й становлять спільний для всіх членів родини «лексичний фонд», найчастотніші в якому - оказіональні найменування, найбільш послідовно експліковані в родинній епістолярії (з-поміж них фіксовано і власні, і загальні найменування). У межах ідіолектів Лесі Українки й Михайла Косача встановлено особливості мотивації, функціонування, типові контексти вживання, сполучувальні можливості, зміни семантичної структури й словотвірні ряди однієї 3 найбільш увиразнених і стилістично маркованих лексем родинної епістолярної комунікації лексеми уліта.
\end{abstract}

Ключові слова: епістолярний текст, родинна комунікація, лексичний регулятив, оказіоналізми.

\section{LESIA UKRAINKA'S EPISTOLARY IDIOLECT IN THE INTERIOR OF FAMILY COMMUNICATION: ULITA}

\author{
Svitlana Bohdan \\ Lesya Ukrainka Volyn National University, Lutsk, Ukraine
}

The article highlights one of the dominant features of Lesya Ukrainka's epistolary idiolect in the context of family communication, which is manifested primarily in the presence of occasional names in the active vocabulary of each member of this family and which serve markers of lexical regulations, characteristic of this family sociolect. On the example of one of such lexical innovations functioning - Ulita, the peculiarities of its origin and motivation in the Kosach family communication have been established (Olga Petrovna Kosach (Olena Pchilka), mother of Lesya Ukrainka, was probably involved in its creation). The study argues that this lexeme is most actively used in the thematic plane of epistolary communication, usually connected with the literary works of the family members. Lesya Ukrainka uses it as a nomination of her own works (first regarding those that are created slowly, then - any work (newly created, old, handwritten, or printed). Quite often, it concerns a separate text variety,

(C) Богдан С., Волинський національний університет імені Лесі Українки, 2020.

Це стаття відкритого доступу на умовах CC BY-NC 4.0 
most frequently, a piece of poetry. The most frequent fixations of this token we observe in the epistolary texts of Lesya Ukrainka and Mykhailo Kosach. The study has revealed a number of productively used derivatives (mostly adjectives and verbs), in particular ulitnyi, ulitiachyi, ulityty, zaulichuvatysia, rozulitytysia and more. An important feature of their functioning in the idiolect of both communicants is their high degree of compatibility, especially the token ulitay, the use of the author's individual derivatives, such as naulicheno, ulityna, ulitynnia, etc. The available graphic markers for the lexemes ulita and ulitnyi in the letters of Lesya Ukrainka and Mykhailo Kosach most probably demonstrate the intertextual status of these tokens and their borrowing from the mother's idiolect, as all other derived tokens of this word-forming series are devoid of such distinction. The active use of such lexical innovations in the epistolary interpersonal communication of the family should be considered as a manifestation of language play within a confined space, partly - a kind of creative entertainment for each of the communicators, a means of stylistic expression of their idiolect, but in no way a manifestation of infantilism or compulsion, initiated by their mother, Olena Pchilka.

Key words: epistolary text, family communication, lexical regulation, occasionalisms.

Вступ. Комунікативний i лінгвоперсонологійний напрями в сучасних мовознавчих студіях чи не найактивніші й актуалізують цілий спектр важливої проблематики. Одна з найпосутніших і перспективних, на наше переконання, проблем, що потребує вивчення у контексті цих напрямів (проте ще мало зреалізована в дослідженнях українських лінгвістів), - специфіка мовної комунікації й вияв спільних та диференційних ознак ідіолектів мовців, котрі належать до певних соціальних груп i спільнот, зокрема й до одного родинного кола, яке нерідко виформовує своєрідний соціолект. Це особливо цікаво, якщо йдеться про родинну комунікацію не в синхронії, а про її реконструкцію в діахронії, що уможливлює пізнати водночас і прикметні ознаки родинної комунікації як елемента мовної парадигми певної епохи, і вплив мовного простору родини (чи його відсутність) на творення ідіолекту кожного члена родини. Власне цим і був мотивований вибір теми нашого дослідження, бо ж відомо, що родинне спілкування Косачів, передусім епістолярне, мало виразні стильові ознаки.

Мета дослідження полягала в з'ясуванні чинників появи однієї 3 лексем, яка належала до активного слововжитку в родинній комунікації Косачів, - уліта, у визначенні мотивації її семантики (як первинних, так і вторинних номінацій) у межах різних епістолярних ідіолектів та пошуку всього реєстру найменувань цього словотвірного ряду й специфіки їх використання в листовній комунікації не лише Лесі Українки, а й інших членів їхньої родини та друзів.

Матеріал і методи дослідження. Матеріалом дослідження слугували дванадцятитомове зібрання творів Лесі Українки (три останні томи в якому становить листовна спадщина) (Українка, Зібрання) й сучасне тритомове видання її епістолярії (Українка, Листи: 1876-1897; Українка, Листи: 1898-1902; Українка, Листи: 1903-1913), а також листи Михайла Косача (Косач) й родини та друзів, уміщені у виданні «Листи так довго йдуть...» (Листи). 
Щоб встановити особливості функціонування лексеми уліта, її сполучувальні можливості й узвичаєні експлікації в епістолярному ідіолекті Лесі Українки використано, крім передбачуваних у такій ситуації методу суцільного вибору, контекстного й дистрибутивного аналізів та лінгвостилістичного спостереження, метод порівняння з текстами інших членів Косачівської родини (батьків, братів-сестер) та їхнього дружньотовариського кола. Принагідно цей метод актуалізовано також для визначення індивідуальності / інтертекстуальності вжитку цієї лексеми в ідіолекті Лесі Українки й родинній комунікації загалом. Метод кількісних підрахунків уможливив визначення продуктивності їі вживання в епістолярних текстах найактивніших користувачів - Лесі Українки й Михайла Косача. Ці дані слугували також основою для визначення динаміки використання номінацій усього реєстру найменувань цього словотвірного ряду в різні періоди листовного спілкування родини.

Результати дослідження та дискусія. Сучасні дослідники все частіше зосереджують увагу на окремих аспектах вияву ідіолекту чи ідіостилю певного мовця (Бойко, і Коткова; Гнатюк; Голікова; Голобородько), почастішали праці про особливості ідіолекту діалектоносів (Глібчук; Глуховцева) тощо. Однак вивчення ідіолекту Лесі Українки дотепер, за поодинокими винятками (Власенко), в основному зосереджено на іï художній мовотворчості (Данилюк; Мацько, і Сидоренко), на з'ясуванні його ролі в історії української літературної мови (Голоюх) тощо. А тому доречним і актуальним вважаємо дослідження епістолярного ідіолекту Лесі Українки, зокрема, передумов формування його стильових домінант у контексті родинної комунікації Косачів.

Як відомо, ідіолект узвичаєно тлумачать як «мовну практику окремого носія мови; сукупність формальних і стилістичних ознак, що вирізняють індивідуальну мову» (Єрмоленко, Бибик, і Тодор 67). У широкому розумінні ідіолект, за визначенням Л. Ставицької, - це «взагалі реалізація певної мови в устах індивіда, тобто сукупність текстів, породжуваних мовцем і досліджуваних лінгвістом 3 метою вивчення системи мови» (3), а у вужчому - «тільки специфічні мовленнєві особливості певного носія мови» (3). Диференційні ознаки кожного мовця щонайперше виявляються на лексичному рівні його ідіолекту. До таких визначальних елементів епістолярної комунікації Лесі Українки, за спостереженнями різних дослідників, належать передусім оказіональні найменування, властиві до того ж листовній практиці й інших членів Косачівської родини. Небезпідставно припустити, що первинна актуалізація багатьох таких лексем мала все ж таки повсякденне спілкування Косачів, а лише згодом була привнесена і в епістолярне. Ймовірно, що саме щоденне міжособистісне спілкування батьків і дітей слугувало джерелом, з якого ці лексеми були привнесені в ідіолект кожного члена цієї родини.

Однією 3 визначальних ознак родинного спілкування Косачів, зокрема епістолярного, правомірно вважають неповторність його стильової 
тональності, котру М. Коцюбинська визначила як своєрідну «метамову», використання якої обмежене колом найближчої родини, зрідка - дружньотовариським, зокрема тим, що перебувало в більш-менш регулярній міжособистісній комунікативній взаємодії (Коцюбинська, Листи і люди 94). Щоправда, цей мовний феномен названий Г. Грабовичем (не зовсім 3 позитивним стилістичним маркуванням і навіть зі зниженою тональністю) «baby talk» (дитинною мовою), «інфантильним дискурсом». Однак, як нам видається, правомірніше все ж таки кваліфікувати цю родинну комунікацію не примітивізацією мовлення Косачів, а, навпаки, виявом своєрідного родинного соціолекту (родинного арґо). Їхня «метамова» - це прийом виразної мовної гри, елемент певного втаємничення міжособистісної комунікації.

Як слушно зазначала М. Коцюбинська, ця метамова «пронизує всі листи й підпорядковує невидимим стильовим законам і умовностям... Вона, справді, $є$ однією з найхарактерніших, сутнісних ознак листування Лесиного родинного кола. Іносказання, алегоричність - найсуттєвіша ознака усного й листовного спілкування Косачів» (Коцюбинська, Зафіксоване і нетлінне 69). Щоправда, такий прийом безперечно зумовлює герметичність i дискомфорт для сторонніх комунікантів, утворює своєрідний обмеженений, закритий комунікативний простір неповторний родинний соціолект. Водночас можна припустити, що створення таких мовних стереотипів певною мірою могло прислужилося до нівеляції індивідуального мовлення Косачів. 3 іншого боку, саме їх наявність виступає своєрідним індикатором (сигналом) спільності тієї чи тієї особистості саме з цим родинним колом.

Важливою диференційною ознакою родинного спілкування Косачів правомірно вважати насамперед (і в цьому одностайні всі дослідники) наявність значного реєстру лексем (як власних, так і загальних), які $\epsilon$ своєрідними маркерами приналежності до цього комунікативного кола. Такі лексеми мають здебільшого статус оказіональних найменувань, а тому уможливлюють порозуміння й адекватність спілкування лише тих комунікантів, які «посвячені» в таїну семантики цих найменувань. Автором певного оказіонального найменування був зазвичай хтось один із родинного «клану». У випадку з Косачами таку «словотворчу» роль (i заохочувально-регулювальну) виконувала, найочевидніше, мати, Ольга Петрівна Косач (Олена Пчілка). Хоча не менш часто появі окремих лексичних новотворів завдячуємо комусь одному з Косачівських дітей, якот: лексема кна-кна - елемент дитячої мови Миколки Косача, Ліля - Ольги Косач тощо, див. детальніше (Богдан) або ж кільком членам родини. Натомість установити походження й вичерпну та переконливу мотивацію деяких із них дотепер залишається неможливим. Це стосується, зокрема, авторства й передумов появи часто вживаного в епістолярних текстах родини лексичного новотвору уліта. 
Це слово безперечно можна вважати регулятивом, своєрідним лексико-семантичним осердям родинної комунікації загалом та ідіолекту багатьох із її членів, навколо якого сформована й функціонує одна 3 найпосутніших тематичних складових (епістолярних мікротем) усієї Косачівської епістолярії - літературна творчість, творча лабораторія кожного з них. А тому її актуалізація представлена зазвичай двовекторно: діти - мати / батько, рідко: друзі - Косачі. Але в кожному конкретному випадку вона завжди проєктована на цю тематичну площину.

Встановлено, що реєстр найактивніших користувачів цієї лексеми в родині Косачів представлений в основному двома персоналіями: Лариса Косач (Леся Українка) і іï брат Михайло. Спорадично лексему уліта фіксовано в листах матері (нечастотність цієї лексеми в її епістолярному слововжитку зумовлена, на наше переконання, лише незначною кількістю листовних текстів цієї адресантки, що стали матеріалом аналізу), батька, Петра Антоновича, та їхніх друзів. Проте вичерпна інформація щодо реальної її актуалізації в ідіолекті кожного члена родини Косачів та їхніх друзів можлива лише за умов видання й приступності для вивчення всієї збереженої епістолярної спадщини. Водночас зауважмо, що левина частка експлікації лексеми уліта, за нашими спостереженнями, припадає на листи, адресовані саме Олені Пчілці.

Найчастотніший вияв ця лексема має, як свідчать кількісні підрахунки, в листах Лесі Українки. Зокрема, лексеми уліта / уліти вжито 40 разів, крім них, є ще 11 фіксацій інших номенів, що утворені від твірної основи уліт-, наприклад: улітний, улітячий, улітічний, улітити, заулітитись. Один раз лексему уліта актуалізовано французькою мовою.

У листах Михайла Косача лексему уліта / Уліта вжито 32 рази, решта фіксацій - похідні найменування: улітина, Улітіння, улітячий, улітять, улітити, улітну (від улітнути), улітяться, розулітився, не заулічуйся (разом - 41 слововживання). Більшість із них можна вважати власне авторськими лексичними новотворами, наприклад: улітина, улітіння, улітнути, улітяться, розулітитися, заулічуватися. Спостережено, що лише в Михайлових епістолярних текстах лексема уліта має паралельне написання 3 малої та великої літер. Графічні маркери він використовував лише щодо трьох лексем - уліта, улітячий і улітити, які належали, до речі, до епістолярного слововжитку і Лесі.

Щоправда, першою в переліку користувачів цієї лексеми, мабуть, логічніше було б усе ж таки назвати Ольгу Петрівну, яка найімовірніше, було автором цього оказіоналізму (подібно до багатьох інших, що становлять диференційні домінанти їхньої родинної метамови), хоча текстових свідчень щодо правомірності таких міркувань у проаналізованих листах нема. I в опублікованій сьогодні мемуаристиці Косачів-Драгоманових вони також відсутні.

Серед комунікантів дружньо-товариського кола Косачів ця номінація також належала, очевидно, до активного словника, однак маємо на 
сьогодні лише поодинокі факти їі вживання, щонайперше - через відсутність вичерпної джерельної бази опублікованих епістолярних текстів, зокрема, їх фіксовано лише у виданні «Листи так довго йдуть...»в епістолярії Лесиної приятельки Маргарити Комарової: «Хоч ти $і$ пишеш, щоб я не дуже радувалась твому приїзду, бо ти засадиш мене ноти писати $i$ сподіваєшся, що й „уліти" [вірші] підуть, але я з радістю жду твого приїзду i зустріну тебе на вокзалі. Ноти писать буду з великою охотою (коли, звичайно, зумію, на що маю надії), але „уліти" не підуть - давно і дуже вже міцно застряли на одному місці, хіба яка „сверхъестественная" сила здвине їх, та й то не підуть, а ледве-ледве поплентаються» (Листи 113).

Коментар редактора щодо вживання цієї лексеми в листі Лесі Українки до матері від 24 січня 1907 р. також не переконлива й достатня підстава твердження щодо Лесиного авторства: «Добре, що мої уліти (так жартівливо Леся Українка (а чи тільки вона? - С.Б.) називала рукописи творів, - Ред.) (Українка, Зібрання 10: 426). Зауважмо, що в дванадцятитомовому виданні маємо кілька пояснень щодо значення слова уліта (пор. : «...Як тільки виправлю свою уліту... - мається на увазі оповідання «Жаль» - перший великий прозовий твір Лесі Українки (Українка, Зібрання 10: 443); «Про улітячу с п р а в у... - Тобто про літературні справи (Українка, Зібрання 10: 439)). Однак ця лексема в Лесиних листах має й інше значення i $\epsilon$ синонімом до найменування відомого літературного товариства «Плеяди»: «Плеяда молодих українських літераторів» (Література, Літературна громадка, Маленька література, Уліта) (Українка, Зібрання 10: 529). До речі, в цьому значенні фіксовано лише одиничну експлікацію цієї лексеми: «Спинюся поки що 3 дальшими радами, бо - entre nous soit dit! (упередженості (франц.)) - хоч би „уліта” сі книжки вивезла, то й то була б доброю робітницею (Українка, Листи: 1876-1897 400). Як бачимо, тут йдеться-таки найімовірніше саме про «літературну громадку».

Не можемо не згадати також перше і чи не єдине найдостовірніше джерело щодо походження й тлумачення цієї лексеми - коментарі Лесиної сестри Ольги Косач-Кривинюк у додатку «Імена, назви, прізвища, прозвища, слова (специфічно вживані в родині Косачів), що зустрічаються в „Хронології життя і творчості Лесі Українки”. Зокрема, щодо значення цієї лексеми вона зауважувала: «Уліта - літературний твір (от «улита едем, когда-то будет») свій, власний», а «Улітити - писати уліти - літературні твори свої власні» (Спогади 151). Як бачимо, в цих коментарях - основне їі значення - не рукопис (як поширено здебільшого в усіх тлумаченнях різних видань листів Лесі Українки), а саме «твір», диференційна ознака якого вказує на його приналежність - власний. Хоча, зауважмо, в епістолярних текстах і Лесі, i Михайла ця ознака значно ширша, бо стосується будь-якого автора 3 їхнього родинного й товариського середовища. Потребує, щоправда, уточнення й Ольжина заувага щодо найменування самого процесу творення, бо лексема улітити, ймовірно, 
стосувалася не лише літературних творів, а й роботи над перекладами (у Лесі), і процесу винахідництва (в Михайла), про що детальніше йтиметься пізніше.

Водночас безпосередньо в примітках авторки в самій «Хронології» подано вужче (узвичаєне тлумачення) цього слова, поширене потім, як уже зазначалося, в усіх виданнях Лесиних листів: «Уліта - літературний твір, свій власний, що дуже поволі пишеться (од „улита едет, когда то будет”)» (Косач-Кривинюк 81). У цьому коментарі маємо, крім того, вербальне увиразнення ступеня вияву повільності написання твору - дуже.

Якщо ж зважити на часові параметри актуалізації лексеми уліта, то перша її фіксація (з-поміж усіх опублікованих текстів родинної епістолярії) припадає на 29 червня1889 року. Це лист Петра Антоновича Косача до Лесі, що майже синхронно відтворює її експлікацію і в доньчиному епістолярному діалозі з матір’ю (26. VI (8. VII). 1889): «Не считаючи вагонного мгновения в Шепетовке, я так давно тебя видел, что ты успела уже возмужать, судя по тому „якою зробилась великою писателькою", и хоть я жалкую, що ты за все время до меня ни слова не написала, але для твого здоровья бажав бы, щоб ты свои писанья, - улит, твор и таке инше, - низвела до минимума. По-моему, и серьезных докторов мнение: всякое писанье вредит успехам лечения, а тебе больше всего следует думать, чтобы выздороветь совсем. И поверь мне, раз будешь здорова, наверстаешь свое, а всякие начинания кна-кон не только от тебя не уйдут, но ты их обгонишь, как обогнала, наприклад, твоя мама» (Листи 46). Для Петра Антоновича уліти, тобто різні «писанья», - причина Лесиного нездоров'я. Незрозуміло, щоправда, чим зумовлена поява в цьому контексті однорідного найменування твор.

Як зазначено в примітках до першої актуалізації цього слова в епістолярному діалозі Лесі Українки з мамою, Ольгою Косач: «Уліта похідне від „Улита едет, когда-то будет”, у родині Косачів це слово означало власний твір, який повільно пишеться» (Українка, Листи: 18761897 64). Тобто ця лексема мала в родинній комунікації статус інтертекстуального елемента. Метафоричний (персоніфікований) статус ії первинної семантичної актуалізації також безперечний. Мотивація лексеми уліта насамперед як рукопису / твору, що поволі / довго створюється безпосередньо проєктована на молюск уліта, тобто на равлика, домінувальна ознака якого в узусі узвичаєно корелює із семантикою 'повільно'.

Подібне тлумачення знаходимо і в наступних томах: «У родині Косачів жартівлива назва літературних творів, що пишуться дуже повільно (похідне від „Улита едет, когда-то будет” (Українка, Листи: 1898-1902 12); «Уліти - твори, що пишуться дуже повільно (жартівливе від „Улита едет, когда-то будет")» (Українка, Листи: 1903-1913 294). Однак беззастережно вважати таке значення цієї лексеми як єдине, мабуть, не правомірно. Таке пояснення цього слова, на наше переконання, стосується радше його 
первинної етимології, про що зрештою стверджує й один із наступних Лесиних листів до цієї ж адресатки зі стилістично маркованою лексемою виразної оцінювальної семантики - лізуть, інтегральна сема якої безпосередньо вказує на повільність процесу створення художніх текстів: «Уліти мої їдуть (лізуть), тілько дуже-дуже помалу..... „когда то будут!"”.... А от Міші стидно, що лінуется писать свою уліту, ажеж здаеться не під тропіками живе, то не повинен би так предаваться dolce far niente (солодкому безділлю (італ.))» (Українка, Листи: 1876-1897 66). Семантично тотожні лексичні ідентифікатори фіксуємо і в інших епістолярних текстах. Нерідко інтенсифікацію ознаки повільності експліковано завдяки прийому редуплікації прислівників ледве-ледве, пор.: «... уліти ледве-ледве лізуть, не пишеться щось, немає жадної рівноваги душі, тепер мене більш ніж коли опанували Drang únd Sturm, тай нема такої конечне наглячої роботи» (Українка, Листи: 1876-1897 116). Доповнюють і увиразнюють цей семантичний ряд й інші дієслівні лексеми, вжиті в листах цього ж епістолярного кола адресантів, пор.: сунулись (Маргарита Комарова до Лесі) («Навіть і... „уліти" трохи сунулись» (Листи 114), брестимуть (Михайло Косач до сестри Лесі) («Як то його уліти і чи хутко дальші брестимуть?» (9. III. [18] 97) (Косач).

Водночас навряд чи можна беззастережно погодитися саме з таким тлумаченням як єдиним і правомірним щодо всіх фіксованих випадків вживання цієї лексеми, зокрема - з однозначністю ії експлікації в усій епістолярній комунікації Лесі Українки і членів її родини. Це переконливо спростовує вже навіть перша Лесина актуалізація лексеми уліта, якщо зважити хоча б на мікроконтекст: «Листи я завжді увечері пишу, бо в день трудно зібратись, якось не йде. Уліти теж на вечір одкладаються» (Українка, Листи: 1876-1897 64). Йдеться, очевидно, про те, що написання і листа, і твору (будь-якого, а не лише того, який «повільно пишеться») потребувало від неї насамперед наявності особливих презупозитивних чинників, які уможливлювали атмосферу зосередженості (вона з'являлася лише за певних ситуативних і часових умов). Власне тих, які забезпечували ефективність творчого процесу.

А тому більш правомірно, за нашими спостереженнями, вважати значення лексеми уліта полісемантичним. Зокрема, одне 3 інших частотних значень цього слова - «твір, який починають / спонукають створювати»: «От тобі, Міша, що ражу: пиши но ти уліти, бо твоя «кушетка» проймае навіки серце ревізмом пойняте» (Українка, Листи: 1876-1897 70), «Я було думала тут зайнятись добре і скінчить нарешті той нещасливий „Жаль”, аж вийшло так, що він і досі лежить нескінчений, а замість його я роспочала ще дві нових уліти: „Les pauvres gens” і одну казку для дитячого журналу, що ми бачили в одессі» (Українка, Листи: 1876-1897 69). Не можна не зауважити в другому цитованому фрагменті ще одне зі значень: уліта в Лесі - це не лише оригінальний твір, а й переклад. Натомість подальший макроконтекст цього листа чітко диференціює 
створення тексту-перекладу і власне художнього тексту, пор.: «Найпильніше тепер мені: "Les pauvres gens» $і$ уліта, а те все ще посnіе» (Українка, Листи: 1876-1897 69).

В окремих контекстах епістолярії Лесі Українки конкретизовано й жанровий статус уліт - вірші: «Переклади не так все таки томлять, як свої уліти, надто коли вірш білий» (Українка, Листи: 1898-1902 43).

Фіксовано також і вужчі значення цієї лексеми, як-от: «нові вірші», тобто ця номінація може стосуватися не всіх, а лише одного з різновидів рукописів художніх текстів - поетичних із диференційною ознакою не «ті, що створені повільно», а «ті, що створені недавно»: «Ти інтересувалась моїми новими віршами, то от їх ціла пачка їде з мамою в Киів, - як бачиш, нічого такого „надзвичайного”, мовляв Бердяєв, у них нема, „уліти” як уліти. Єсть у мене і де-які инші писання, та то все „не до громадської відомости"» (Українка, Листи: 1898-1902 11-12).

Ще одне зі значень лексеми уліта в Лесиній епістолярї - чорновий автограф: «Моя бідна „Ia grande Oulita” („Велика уліта” (франц.)) тепер може і на миші переведеться не переписана, коли не найдеться спасенної душі, щоб переписала, бо не хутко дочекається вона чести мого власноручного переписування...» (Українка, Листи: 1876-1897 100).

Не менш частотна актуалізація цієї лексеми і як творів уже надрукованих («Біда нашим улітам з критикою, як от моїй тепер, один зовсім на смерть осудив, а другий не прибере місця де посадити! (йдеться про оповідання Лесі Українки „Жаль”, котре по-різному оцінили М. Павлик та I. Франко: перший розкритикував твір, а другий виявив бажання друкувати його окремою книжкою. - прим.) хто зна, як і судити тепер, хіба треба взяти середину, як завжді в таких випадках» (Українка, Листи: 1876-1897 138)), і не лише окремих, але й цілих збірок («Ага, от що: моя нова книжечка віршів („Відгуки”) вже вийшла і мені прислана, гарненько видана і в гарній оправі. Тепер вже всі „уліти з'їхались”» (Українка, Листи: 1898-1902 446)).

Однак чи не найчастіше в епістолярних текстах Лесі Українки лексема уліта виступає абсолютним синонімом будь-якого твору, не лише власного: «Ще ти мене питала про улітu, та от що скажу: Douх роétes («Лагідних поетів» (франц.). - ідеться про Лесин переклад поезії В. Гюго «Лагідні поети, співайте!». - прим.)... у мене нема при собі, а ти їх можеш знайти в синій тетраді з віршами, що зосталася з иншими улітами, здається, у плетеній скрині, там же і Пінгвін» (Українка, Листи: 1876-1897 143).

В ідіолекті інших комунікантів спостережена певна спеціалізація використання лексеми уліта в одному з потенційних значень. Скажімо, для Михайла Косача уліти - це, очевидно, здебільшого всі художні твори: «Які то уліти тепер у вас з Лесею улітяться, чи драма, чи проза, чи вірш. Які у цензурне чистилище пішли?» (Михайло до батьків, [Дерпт] 26. ХІІ. 99) (Косач), рідше - лише вірші: «..як Зеїсок мається, - боюсь я дуже за його нерви, Київ не дуже то їм сприяти мусить, - як йдуть ваші уліти та 
драми. Напрасне Зеїсок так відноситься до видання віршів, що їх конешне мусить сам автор переписувати» (Михайло до матері, 17. XI. 98?) (Косач). Кілька раз цю лексему вжито щодо поетичних текстів сестри зі стилістично забарвленим епітетом легкоскрилений / легковскрилений: «Як твої уліти, ти пишеш, що знов до них узялася, але не пишеш, до чого власне, а це мені цікаво знати, чи легкоскрилений іде, чи проза чимчикує» (Михайло до Лесі, 18.08.1991) (Косач); «Вірша деякого легковскриленого не пошкодило б мені прислати» (Михайло до матері та Лесі, 16.12.1898) (Косач).

Значно розширюють семантичну структуру лексеми уліта інші найменування всього деривативного ряду оказіоналізмів, похідних від нього. Зокрема, процес створення якогось тексту (тобто уліт) експліковано в листах Лесі Українки передбачувано - найчастіше за допомогою дієслова улітити («Що ж ти тепер робиш, чі в математіку затопився, чі по Киіві прохоложуешся, чі може що улітиш?» (братові Михайлові) (Українка, Листи: 1876-1897 69), а його завершення - доулітити: «Ну, та дасть Біг, доулічу все благополучно» (Українка, Листи: 1876-1897 69). Якщо йшлося про написання не одного твору, а кількох / багатьох, Леся Українка вживала оказіоналізм заулітитись: «Оце з початком весни я все частіше звертаю свої думки на різні уліти і, коли б не боялась заулітитись, то писала б певне» (Українка, Листи: 1898-1902 43). Як бачимо, ймовірний процес інтенсивного творення мав несподіваний, на перший погляд (але зовсім природній для адресантки), емоційний асоціат - боязнь / острах, зумовлений, як відомо, постійним і закономірним наслідком Лесиного невтоленного творення, що призводив іï до надмірного фізичного виснаження.

Лише один раз у листі Михайла Косача на позначення процесу творення фіксовано іменник улітіння, який, щоправда, стосується створення не художніх текстів, а моделювання певних пристроїв: «Про себе мушу сказати, що на мене знов напала течія „откритій і ізобретєній”. Єсть тут один студент, дуже способний хлопець, але дуже вже розкидується він. „Ізобретатель”, але більша часть його видумок якісь не доведені до кінця. Отож він своїми різними вигадками та розсказами якось так підганяє і накеровує думку, що оце я знов не маю покою і все думаю тепер над дешевим таксометром, себто машинкою такою, щоб як от у берлінських звощиків показувала, скільки проїжджено і скілько платить треба. Берлінські таксометри каторжно дорогі - 450 марок. У мене уже єсть скелет ідеї, не знаю, скілько буде приряд коштувати з м'ясом $i$ кістками? Думаю, що небагато. Заробити на цьому можна б добре, бо попит на таксометри тепер великий. Треба буде хутній виробити ідею вконець, яко швидше, щоб хоч позбутись ї̈, а то не дає вона мені спокою, иозолить та мозолить голову оце зо вчорашнього дня. Кілька вже таких ідей у мене записано, лежать і не турбують, От і ия, як перестане бути незаписаною, то й не буде сушити голови. Все одно як уліта яка. Се теж свій 
род Улітіння. Про цеє варто було б колись написати Уліту. Може, $i$ напишу» (Михайло до матері та Лесі, 17.03.1899) (Косач). У цьому фрагменті спостерігаємо своєрідну образну градацію - послідовну актуалізацію кількох образних елементів: первинна метафоризація (уліта як рукопис ( твір) - порівняння як уліта - створення індивідуального лексичного новотвору для процесу творення таксометра (улітіння) розширення семантичної структури початкової номінації (вторинна метафоризація) уліта - будь-яка творча дія).

Неспростовність і умотивованість наших міркувань щодо полісемантичності цієї лексеми переконливо ілюструють також контексти вживання інших похідних найменувань, зокрема прикметникових. Щонайвиразніше це актуалізовано в різноманітних атрибутивних словосполученнях, позначених емоційно-експресивним забарвленням, якот у Лесиному вислові на зразок «наступає знову мій неудержимий улітний період», який можна кваліфікувати як бінарну опозицію щодо первинного значення цієї лексеми, одним зі стилістичних маркерів якої слугує лексема неудержимий, тобто той, який позначений вирізнювальною семою 'швидкість': «Я тепер по троху вже починаю уліти писать, чую, що вже наступає знову мій неудержимий улітний період, отже, значить, писатиму. Чі ти улітіш, чі ні? Може тебе так замучила малина, клубніка, тигри-негри і лиси, що вже й не до уліт?» (Українка, Листи: 1876-1897 136). Ця ж домінантна сема 'швидко' в її епістолярних текстах була зреалізована й стереотипним для мовлення поліщуків сталим тавтологічним висловом летом летіли (подібно до бігом бігли): «Уліти мої остатнього часу летом летіли, тепер трошки притихли, а далі знов полетять. Я скінчила "Давню казку" (поет і лицарь), прочитала їі в плеяді з певним тріумбом, найбільш всіх сподобалась вона паничеві Ліпскому, се мені приємно, бо все таки він людина, вихована на европейській літературі і патріотичної поблажливости у нього нема» (Українка, Листи: 1876-1897 233).

Лексема уліта позначена високим рівнем сполучуваності, зокрема, це стосується прикметникових поширювачів, які вказують здебільшого на iї різновиди, оцінні характеристики, авторство, розміри, кількісні параметри: виставочна (Михайло до матері, 07.06.1896) (Косач), давні (Михайло до матері, 21.12.1896) (Косач), де-які (Українка, Листи: 19031913 294), добрі (Михайло до матері, [1897]) (Косач), инші (Українка, Листи: 1876-1897 143), кричущі (Українка, Листи: 1876-1897 140), нові (Михайло до матері, 21.12.1896) (Косач), (до батьків, 01.01.1899) (Косач), святкова (Михайло до матері, 21. XII. [18]96) (Косач), старі (Михайло до Лесі, 28.10.1890) (Косач), маленькі (Михайло до матері, 21.12.1896) (Косач), фбантастична (Українка, Листи: 1903-1913 533), чудесниї (Михайло до матері та Лесі, 16.12.1898), юморістичні (Українка, Листи: 1876-1897 143) тощо. Іноді такі означення можуть поєднуватися: моя бідна «la grande Oulita» (Українка, Листи: 1876-1897 100), дві нових уліти (Українка, Листи: 1876-1897 100) тощо. 
Означення фантастична має єдину фіксацію в епістолярії Лесі Українки і стосується жанрового різновиду «Лісової пісні». У листі до матері 16 липня 1911 року вона з Кутаїсі повідомляла про початок роботи над цим твором («Взялась я до нової уліти - фбантастичної на сей раз voila!» (Українка, Листи: 1903-1913 533)), який, як відомо, був створений упродовж 10-12 днів («Правда, писала я їі дуже недовго, 10-12 днів, і не писати ніяк не могла, бо такий уже був непереможний настрій; але після неї я була хвора і досить довго „приходила до памяти” (Українка, Листи: 1903-1913 554)), а тому нема щонайменших підстав вважати цю уліту такою, що містить первинну сему 'повільно'. До речі, це була загалом остання фіксація лексеми уліта в її епістолярному ідіолекті.

Найчастіше атрибутивні словосполучення (зовсім передбачувано) увиразнені присвійними прикметниками мій, свіŭ, твій, наші, ваші, що слугують додатковим маркером поширеності одного зі значень цієї лексеми як власного твору, і лише згодом - чужого, наприклад: свої уліти (Українка, Листи: 1903-1913 129), мої уліти (Українка, Листи: 1903-1913 140), нашим улітам (Українка, Листи: 1903-1913 138) - у Лесі, мої уліти» (8.01.1890) (Косач), ваші уліти - твої і Лесині (07.06.1896) (Косач) Михайло до матері тощо.

Щоправда, деякі з висловлень із атрибутивним компонентом «улітний» мають в епістолярних текстах статус інтертексту, а тому потребують аргументованого й адекватного тлумачення, що виявляється не завжди можливим, бо його сучасний коментар ґрунтується на суб'єктивних припущеннях, який, зрозуміло, не виключає очевидних похибок. Скажімо, Леся Українка, цитуючи в одному з листів маму, використовує вислів «на улітний конт»: «Я забула попросить тебе внести за мене в Літературне товариство, вони требували з мене ще, як я була в Київі проїздом з Берліна, та я тоді ніяк не могла того зробити, а тепер боюсь, ще виключать із членів, сором буде. Слід би не гаятись і з Общ[еством] Драм[атических] писателей, та то ще є час. Се все „на улітний конт”, як ти часом говориш. Вибачай, що завдаю тобі клопіт, нарешті, як се загайно, то не возись» (Українка, Листи: 1898-1902 156). У словнику Б. Грінченка слово конт актуалізовано зі значенням «Продовольствіе, съђстные припасы» (Словарь 2: 279). В одинадцятитомовому «Словникові української мови» воно загалом відсутнє. Можна лише припустити, що йдеться, ймовірно, про те, що уліти могли б стати джерелом фінансових надходжень для термінових видатків, про які йдеться в листі.

«Лапковим» увиразненням у листах Лесі й Михайла іноді позначені також ще дві інші лексеми «уліта» й «улітний». Однак графічне маркування цих лексем не супроводжене жодними коментарями адресантів і вказівками на авторство. Водночас саме таке увиразнення слугує підставою для твердження, що в такий спосіб комуніканти прагнули підкреслити оказіональний статус цих лексем, вирізнити обмеженість уживання цієї лексеми лише родинним колом. Хоча не менш 
вірогідно, що власне таким чином закцентовано імпліцитно на їхній інтертекстуальності, її запозиченості з мовлення інших членів родини. Найчастіше таке використання номінації уліта / уліти (й похідних лексем) властиве епістолярному спілкуванню Лесі Українки з мамою і з братом Михайлом, а також Михайла Косача з мамою і з Лесею, пор. : «Позавтрому тут в театрі Гарин і Станюкович мають читати прилюдно свої „уліти”, піду, послухаю, які то літературні вечорі „у здьшняго государя” бувають, воно ж до речі й розривка буде» (Українка, Листи: 1876-1897 167); «Я не писала сії дні тобі на відповідь, бо дуже була занята „улітами"» (Українка, Листи: 1903-1913 342) і «Як ваші „уліти” ідуть?» (Михайло до матері, [весна 1900]) (Косач); “А як твої „уліти” і Зеїскові маються. Дуже цікавий я усе знати, бо коли самому не вільно „улітити”, то хоч почути, як другі „улітять”. А рropos „уліт”, Потапенко розулітився страшенно, скрізь його оповідання [...], то аж цілий величезний роман, на широкий замах початий [...]; що то воно далі буде, а початок я трохи переглянув, вельми цікавий з „улітячого” боку» (Михайло до матері, 18.09.1991) (Косач). Хоча в останньому цитованому фрагменті не зовсім зрозуміла мотивація «розлапкування» однієї з лексем цього ж деривативного ряду - розулітився. Ймовірно, таким чином диференційовано власний лексичний новотвір на противагу всім іншим, запозиченим із ідіолекту когось із членів родини.

Деривативний ряд похідних найменувань представлений в ідіолектах брата й сестри в основному іменниками й прикметниками, які називають процес творення різних текстів (улітіння, улітити, улітнути, улітяться, розулітитися, заулічуватися - у листах Михайла, улітити (улітить), заулітитись (заулітилась), доулітити (доулічу) - у листах Лесі), характеризують різні аспекти творчості (улітяча / - ий / справа (Українка, Листи: 1876-1897 64), бік (Михайло до матері, Dorpat, 18. IX. 91 р.) (Косач)); улітічна / звістка (Українка, Листи: 1876-1897 64); улітний / конт (Українка, Листи: 1898-1902 156), період (Українка, Листи: 1876-1897 134) тощо.

Один раз у листі Лесі Українки вжито оказіональний прислівник наулічено (ймовірно, створений саме нею) (Українка, Листи: 1876-1897 134). У Михайла Косача спостережено також єдину фіксацію похідної номінації улітини, яка актуалізує, найімовірніше, сему зменшувальності, продубльованої до того ж прикметниковим повтором маленькі («A propus уліт, посилаю оце тобі дві улітини маленьких: одну давню, їі Максим знає, другу - нову. Єсть у мене одна святкова уліта, але вона не докончена: я їі на святах кінчу» (Михайло до матері, 21.12.1896) (Косач)). Привертає увагу й те, що лексема уліти представлена в межах одного мікроконтексту двома їі основними значеннями: творів-текстів - і давніх, і нових.

Номінація уліта / уліти виступає в аналізованих епістолярних текстах і об'єктом, і суб'єктом дії. Вони поєднані головно з дієсловами (рідко дієприкметниками): писати / не писати (найчастіше), написати, починати писати, питати (про), взятись (до писання), взятись (до уліти), 
роспочати, одкладати, скінчати, читати, читала (із уліт), зайнята / занята, попідкінчувати, виправляти, зіставити, томлять, розказати (про), присилати, послати, посилати, жадати, привезти, навезти, улітнути тощо. У ролі суб'єкта узвичаєно маємо експлікацію персоніфікованих конструкцій із різним стилістичним забарвленням: лізти, притихати, зостановилися, брестимуть, посуваються, іти / йти, їхати, з'їжджатися (з'їхались), зостались, поводяться, маються, поводяться, поробляють, летіти, летом летіти, полетіти тощо.

Михайло Косач у листах щонайбільше цікавиться творчістю «улітними справами» - своїх двох найшановніших авторок - матері («милої мами») й сестри Лесі («коханого / любого Зеїска»), у значущості слова яких для прийдешнього в нього не було жодних сумнівів. Зокрема, в листі до сестри 18 серпня 1981 року він писав: «Пісня твоя не вмре, не загине. Ти $i$ мама мені здаєтесь Жорж Занд і Сталь нашої літератури. Ви з честю пишете свої ймення [на] скрижалі історії. За нас будущина, відродження демократизму і любові до ближнього» (Косач).

Найчастотніша й типова актуалізація цієї лексеми в листах Михайла Косача - запитальні контексти наприкінці епістолярної комунікації ( $Я$ Як ваші „уліти" ідуть? Що ти тепер пишеш і що думаєш писати?» (до матері, [весна 1900] (Косач); «Як твої уліти?» (до Лесі, 18.08.1991) (Косач); «А як твої „уліти” і Зеїскові маються» (до матері, 18.09.1991) (Косач); «Ще більше я цікавий за ваші уліти - твої і Лесині. Що то ви там понаписували?» (до матері, 07.06.1896) (Косач); «Як взагалі ваші уліти маються і поводяться?» (до Лесі, Dorpat. 23. II. [18] 97) (Косач); «Пиши, будь ласка, як ви ся маєте усі і ти особисто та твої уліти?» (до матері, 26.09.1897) (Косач); «Як ваші уліти і Літературне Товариство?» (до матері, 22. I. 00) (Косач)) й вітально-побажальний дискурс (здебільшого на початку) («3 весною, з літом новим будь здорова, з новими улітами, новими n'єсами» (до матері, 04.1897) (Косач); «Жадаю добрих уліт $i$ всякого поспіху» (до матері, [1897]) (Косач); «3 новими силами, з новим здоров'ям, з новими улітами, з новими працями, з новою господаркою» (до батьків, 01.01.1899) (Косач)).

У спілкуванні з мамою Леся Українка, подібно до брата, також часто цікавиться процесом творення: «Як твої уліти? etc. etc. etc. - Все хочу знати» (Українка, Листи: 1876-1897 114); «Як маються твої уліти, а надто юморістичні, що ти колись про них згадувала, чі вже скінчені?» (Українка, Листи: 1876-1897 266); «Чі багато уліт наулічено?» (Українка, Листи: 1876-1897 398).

Водночас не можна не звернути увагу на своєрідну опозитивність Михайлового ставлення до процесу творчості любої сестри. 3 одного боку, він не раз висловлює емоції втіхи й гордості щодо такої бажаної творчості

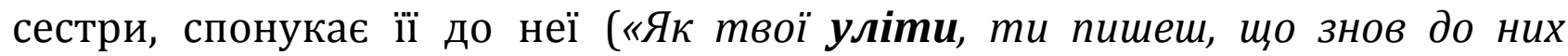
узялася, але не пишеш, до чого власне, а це мені цікаво знати, чи легкоскрилений іде, чи проза чимчикує» (до Лесі, 18.08.1991) (Косач). Про 
надмірне братове захоплення ії творчістю Леся Українка зауважила в одному з листів, вдавшись до трансформації відомого бібліїзму: «...Міша то смішить мене навіть своїми дифірамбами; певне то неправда, що неможна бути пророком в рідному краю, бо отже можна ним бути навіть в очах рідного брата» (Українка, Листи: 1876-1897 173). А з іншого (подібно до батька, Петра Антоновича), Михайло турбується, щоб творчість не втомила її і створює для ословлення цього прохання власний дієслівний новотвір заулічуватися: "I взагалі, Зеїску, не заулічуйся [...], а то ти можеш і три години з розгону просидіти» (до Лесі, 18.08.1891) (Косач). Зрештою, Леся й сама неодноразово зізнавалася своїм найближчим адресатам про те, що уліти були нерідко передумовою їі проблем зі здоров'ям. А це спонукало її почасти до зміни роду творчої діяльності: «Переклади не так все таки томлять, як свої уліти, надто коли вірш білий» (Українка, Листи: 1898-1902 43).

Водночас Лесю хвилювала відсутність бажання творити в брата Михайла. Ймовірно, це зумовлено насамперед тим, що написання художніх текстів належало до бажаних способів самореалізації всіх Косачівських дітей. До цього заохочувала їх, як відомо, Олена Пчілка. Про відсутність братового «улітіння» Леся Українка неодноразово пише в листах до матері: «А от Міші стидно, що лінуется писать свою уліту, ажеж здаеться не під тропіками живе, то не повинен би так предаваться dolce far niente (солодкому безділлю (італ.)» (Українка, Листи: 1876-1897 66); «Кна-кна нічого не робить і не улітить, а тілько читає та спить, та до пізна над морем сидить укупі зо мною» (Українка, Листи: 1876-1897 137).

Із листів Михайла Косача відомо, що процес творення художніх текстів приносив йому позитив і задоволення, а тому неможливість творити в час його навчання й праці через зайнятість професійними справами була для нього невтішною: «Дуже цікавий я усе знати, бо коли самому не вільно „улітити”, то хоч почути, як другі „улітять”. А propos „уліт"» (до матері, 18.09.1991) (Косач). Власне тому він так чекав слушної нагоди відновити цей процес творення. У листі від 28 квітня 1898 року $з$ Дерпта до матері Михайло і пише про таку можливість після сесії. Найвиразніше цей його емоційний стан щодо очікуваної творчої самореалізації відтворено оказіональним тавтологічним висловом уліту улітну: «Ну та нехай уже екзамени здам, тоді, як од своїх математикофізик одтрясуся, то вже уліту улітну так-так» (Косач). Пор. також фрагмент іншого листа: «Ну та цей стан мусить хутко скінчитись, або сьогодня, або завтра, а тоді перед виїздом і дорогою можна і до уліт; бо охота до писання починає таки добре забиратись» (до Лесі, Колодяжно. 18. VIII. 91 p) (Косач).

Однак не завжди бажання Косачів творити й життєві реалії були гармонізовані, а тому в епістолярних текстах фіксуємо чимало експлікацій перешкод «улітній справі», 3-поміж яких найчастотніші: побутові й професійні проблеми (в Олени Пчілки, в Михайла Косача) й погане здоров'я 
(в Лесі): «Чі ти улітиш, чи ні? Може, тебе так замучила малина, клубника, тигри-негри і лиси, що вже й не до уліт?» (Українка, Листи: 1876-1897 136); «Хотілось би мені поїхати у февралі в Колод[яжне], бо втомив мене Київ і неприємно мені, що папа все сам там сидить, але і тут буде без мене недобре, бо утятко буде пів дня з Фросею само, а се теж недобре. То я собі все думаю, та ніяк не придумаю, що його робити. Може таки на тім тижні поїду. Було б се добре щей тим, що попідкінчувала б деякі уліти, бо тут їм все „Бог спору не дає”: або люде раз у раз вештаються, або всякі слабості та карантини угнітають - якась погана була ия зіма» (Українка, Листи: 1903-1913 294); "Думала вже на свята взятись до писання листів і уліт, „но не тут-то было”; вже в першу великодню ніч мусила я сама себе одливати водою» (Українка, Листи: 1898-1902 198).

Водночас періоди творення уліт і їх відсутність у Косачівській родині закономірно були позначені плинністю і динамікою. А тому епістолярні тексти дають можливість відтворити емоційний настрій адресатів у ці різні періоди. Із властивою для Лесі Українки «трагічною оптимістичністю» в одному з листів вона пише про те, що стан, коли повертається натхнення й творення, - неминучий після того, як настає творча тиша: «Уліти мої остатнього часу летом летіли, тепер трошки притихли, а далі знов полетять» (Українка, Листи: 1876-1897 233).

Висновки й перспективи дослідження. А отже, функціонування лексеми уліта й похідних найменувань цього словотвірного ряду в епістолярних ідіолектах Лесі Українки, брата Михайла, їхніх батьків та друзів стверджує припущення про їх регулятивний статус як одного зі спільних диференційних і концептуальних понять цієї родинній комунікації. Як елемент особливої метамови Косачівської родини ці лексичні новотвори актуалізовані здебільшого в листах, що містять мікротему «літературна творчість».

Найчастотніші фіксації лексеми уліта спостережені в епістолярних текстах Лесі Українки й Михайла Косача, в яких наявний цілих ряд продуктивно вживаних похідних (здебільшого прикметникових і дієслівних) найменувань, зокрема улітний, улітячий, улітити, заулічуватися, розулітитися тощо. Важливою особливістю їх функціонування в ідіолектах обох комунікантів можна вважати високий ступінь сполучуваності передусім лексеми уліта й індивідуально авторське вживання власне авторських похідних найменувань, наприклад, наулічено, улітіння, улітина тощо.

Наявні графічні маркери щодо лексем уліта й улітний в листах Лесі Українки й Михайла Косача вказують найвірогідніше на інтертекстуальний статус цих лексем і запозичення їх з ідіолекту матері, оскільки всі інші похідні лексеми цього словотвірного ряду позбавлені такого вирізнення.

Активне використання зафіксованих лексичних новотворів в епістолярному міжособистісному спілкуванні родини варто вважати виявом мовної гри в межах замкненого простору і маркером приналежності до 
нього, почасти - різновидом словотворчої забави для кожного з комунікантів, засобом стильового увиразнення їхнього ідіолекту, але в жодному разі не виявом «інфантильності» чи, тим паче, - примусу, ініційованого матір'ю, Оленою Пчілкою.

Кількісні параметри актуалізації цих лексем у слововжитку Косачів, зокрема Лесі Українки й Михайла Косача, засвідчують виразну й посутню закономірність: їх експлікація виразно зменшується з роками, тобто має спадну динаміку.

Подальше вивчення цієї проблеми полягатиме в дослідженні особливостей побутування інших визначальних елементів Косачівської метамови, які становить ядро їхнього родинного соціолекту.

\section{Список використаної літератури}

Богдан, Світлана. «Оказіональні найменування номінативного поля дитина в епістолярних текстах Лесі Українки». Лінгвостилістичні студії, вип. 3, 2015, с. 6-36.

Бойко, Надія, і Коткова, Людмила. Експресивний потенціал ідіолекту Володимира Винниченка: лексичні та фразеологічні складники. Ніжин, 2017.

Власенко, Валентина. «Мовна особистість Лесі Українки в епістолярному дискурсі». Ученые записки Таврического национального университета имени В. И. Вернадского. Серия «Филология. Социальные коммуникации», т. 25 (64), № 1, часть 2, 2012, с. 349-54.

Глібчук, Наталія. «Ідіолект Парасковії Павлюк крізь призму діалектних текстів». Діалекти в синхронії та діахронії: текст як джерело лінгвістичних студій. Київ, 2015, с. 60-74.

Глуховцева, Катерина. Дискурсивність особистості діалектоносія. Science and Education a New Dimension. Philology, III(11), вип. 56, 2015, с. 48-51.

Гнатюк, Лідія. Мовний феномен Григорія Сковороди в контексті староукраїнської книжної традиції. Київ: Видавничо-поліграфічний центр «Київський університет», 2010.

Голікова, Наталія. Мова художньої прози Павла Загребельного: від слова до концепту. Дніпро, 2018.

Голобородько, Костянтин. Ідіостиль Олександра Олеся: лінгвокогнітивна інтерпретація. Харків: Харківське історико-філологічне товариство, 2010.

Голоюх, Лариса. «Ідіолект Лесі Українки в історії української літературної мови». Лінгвостилістичні студії, вип. 12, 2020, с. 28-36.

Грабович, Григорій. «Кобзар. Каменяр. Дочка Прометея». Критика. № 12.1999 , с. 16-9.

Данилюк, Ніна. «Лексика зі стилістичним значенням у збірці Лесі Українки 'На крилах пісень' (1893 р.)». Лінгвостилістичні студї, вип. 1, 2014, с. 70-9.

Єрмоленко, Світлана, Бибик Світлана, і Тодор, Олена. Українська мова. Короткий тлумачний словник лінгвістичних термінів. Київ: Либідь, 2001.

Косач-Кривинюк, Ольга. Леся Українка. Хронологія життя i творчости. Луцьк: Волинська обласна друкарня, 2006.

Косач, Михайло. Твори. Переклади. Листи. Записи кобзарських дум, упоряд. Л. Мірошниченко. Київ: Видавничий Дім «КОМОРА», 2018.

Коцюбинська, Михайлина. Зафіксоване і нетлінне. Київ: Дух і літера, 2001.

Коцюбинська, Михайлина. Листи і люди. Роздуми про епістолярну творчість. Київ: ДУХ і ЛIТЕРА, 2009.

«Листи так довго йдуть...»: знадоби архіву Лесі Українки в Слов'янській бібліотеці у Празі, упоряд., передмова та прим. С. Кочерги. Київ: Просвіта, 2003. 
Мацько, Любов, і Сидоренко Олеся. «Лінгвостилістичний погляд на мовний світ Лесі

Українки». Лінгвостилістичні студії, вип. 1, 2014, с. 135-45.

Словарь української мови, за ред. Б. Д. Грінченка. В 4 т. Київ, 1907-1909.

Словник української мови, за ред. І. К. Білодіда. В 11 т. Київ: Наукова думка, 1970-1980.

Спогади про Лесю Українку, автор проекту та відповідальний редактор Т. Скрипка. У 2 т.

Нью-Йорк-Київ: Темпора, 2016-2017.

Ставицька, Леся. «Про термін ідіолект». Українська мова, №4, 2009, с. 3-17.

Українка, Леся. Зібрання творів. В 12 т. Київ: Наукова думка, 1975-1979.

Українка, Леся. Листи: 1876-1897, упоряд. Прокіп (Савчук) В. А. Київ: Комора, 2016.

Українка, Леся. Листи: 1898-1902, упоряд. Прокіп (Савчук) В. А. Київ: Комора, 2017.

Українка, Леся. Листи: 1903-1913, упоряд. Прокіп (Савчук) В. А. Київ: Комора, 2018.

\section{References}

Bohdan, Svitlana. “Occasional Nominations of the Nominative Field Child in Lesya Ukrainka's Epistolary Texts". Linguostylistic Studies, no. 3, 2015, pp. 6-36.

Boiko, Nadiia, and Kotkova, Liudmyla. Ekspresyvnyi potentsial idiolektu Volodymyra Vynnychenka: leksychni ta frazeolohichni skladnyky. Nizhyn, 2017.

Vlacenko, Valentyna. "Personality of Lesia Ukrainka in Epistolary Discourse". Scientific Notes of the Taurida National V. I. Vernadsky University. Series: Philology. Social Communications, vol. 25 (64), no. 1, part 2, 2012, pp. 349-54.

Hlibchuk, Nataliia. "Paraskoviya Pavliuk's Idiolect Through the Prism of Dialect Texts". Dialekty $v$ synkhronii ta diakhronii: tekst yak dzherelo linhvistychnykh studii. Kyiv, 2015, pp. 60-74.

Hlukhovtseva, Kateryna. "Discursitive of dialect speaker personality". Science and Education a New Dimension. Philology, III(11), iss. 56, pp. 48-51.

Hnatiuk, Lidiia. Movnyi fenomen Hryhoriia Skovorody v konteksti staroukrainskoi knyzhnoi tradytsii. Kyiv: Vydavnycho-polihrafichnyi tsentr "Kyivskyi universytet", 2010.

Holikova, Nataliia. Mova khudozhnoi prozy Pavla Zahrebelnoho: vid slova do kontseptu. Dnipro, 2018.

Holoborodko, Kostiantyn. Idiostyl Oleksandra Olesia: linhvokohnityvna interpretatsiia. Kharkiv: Kharkivske istoryko-filolohichne tovarystvo, 2010.

Goloyukh, Larysa. "Lesya Ukrainka's Idiolect in the History of the Ukrainian Literary Language". Linguostylistic Studies, iss.12, 2020, pp.28-36.

Hrabovych, Hryhorii. «Kobzar. Kameniar. Dochka Prometeia». Krytyka, no. 12, 1999, pp. 16-9.

Danylyuk, Nina. "Words With Stylistic Meaning in the Collection of Poetry "Na Krylah Pisen (On the Wings of Songs)" by Lesya Ukrainka (1893)". Linguostylistic Studies, iss. 1, 2014, pp. 70-9.

Yermolenko, Svitlana, Bybyk Svitlana, and Todor, Olena. Ukrainska mova. Korotkyi tlumachnyi slovnyk linhvistychnykh terminiv. Kyiv: Lybid, 2001.

Kosach-Kryvyniuk, Olha. Lesia Ukrainka. Khronolohiia zhyttia i tvorchosty. Lutsk: Volynska oblasna drukarnia, 2006.

Kosach, Mykhailo. Tvory. Pereklady. Lysty. Zapysy kobzarskykh dum, edited by L. Miroshnychenko. Kyiv: Vydavnychyi Dim "KOMORA", 2018.

Kotsiubynska, Mykhailyna. Zafiksovane i netlinne. Kyiv: Dukh i litera, 2001.

Kotsiubynska, Mykhailyna. Lysty i liudy. Rozdumy pro epistoliarnu tvorchist. Kyiv: DUKh i LITERA, 2009.

"Lysty tak dovho ydut...": znadoby arkhivu Lesi Ukrainky v Slovianskii bibliotetsi u Prazi, edited by S. Kocherha. Kyiv: Prosvita, 2003.

Matsko, Lyubov, and Sydorenko, Olesya. "The Linguistic View on World Language Lesya Ukrainka's". Linguostylistic Studies, iss. 1, 2014, pp. 135-45.

Slovar ukrainskoi movy, edited by B. D. Hrinchenko. 4 vols. Kyiv, 1907-1909. 
Slovnyk ukrainskoi movy, edited by I. K. Bilodid. 11 vols. Kyiv: Naukova dumka, 1970-1980.

Spohady pro Lesiu Ukrainku, edited by T. Skrypka. 2 vols. Niu-York-Kyiv: Tempora, 20162017.

Stavytska, Lesia. "Pro termin idiolekt". Ukrainska mova, no. 4, 2009, pp. 3-17.

Ukrainka, Lesia. Zibrannia tvoriv. 12 vols. Kyiv: Naukova dumka, 1975-1979.

Ukrainka, Lesia. Lysty: 1876-1897, edited by V. A. Prokip (Savchuk). Kyiv: Komora, 2016.

Ukrainka, Lesia. Lysty: 1898-1902, edited by V. A. Prokip (Savchuk). Kyiv: Komora, 2017.

Ukrainka, Lesia. Lysty: 1903-1913, edited by V. A. Prokip (Savchuk). Kyiv: Komora, 2018.

Стаття надійшла до редколегії 11.10.2020 